\title{
The Correction of Self-Image as One of Directions of Work for Preventing Victimization of People with Crippled Body in Modern Russian Society
}

\author{
Lyubov A. Nagornaya*a and Nikolay N. Nagornyi ${ }^{\text {b }}$ \\ a Siberian Federal University \\ 79 Svobodny, Krasnoyarsk, 660041, Russia \\ ${ }^{b}$ Siberian Law Institute of Federal Drug Control Service of Russia \\ 20 Rokossovskii, Krasnoyarsk, 660131, Russia
}

Received 11.04.2015, received in revised form 20.05.2015, accepted 19.07.2015

The article analyzes the reasons for the victimization of people with mutilated corporeality. It is noted that the conditions of socialization of people in modern Russian society contribute to the formation of victim behavior. The paper defines basic directions of work for the prevention of victimization of people with mutilated corporeality in modern Russian society. The basic position of the work is to create a positive self-image of a person with crippled corporeality as one of the areas of work for the prevention of victim behavior of people with mutilated corporeality.

Targeted, comprehensive, consistent influence of the main institutions of socialization for people with mutilated corporeality is more important than for people with full corporeality. The human physicality often becomes crippled by the impact of unfavorable conditions of socialization. Subsequently, a person with already crippled corporeality may continue to be adversely affected by socializing through the basic institutions of public life. Thus, in the future crippled physicality of life there is often a person with something that has not been healed, and has even become more damaged than it had been originally (since its initial injury).

Modern Russian society creates a large number of stressful situations for people with mutilated corporeality (in particular, many people with disabilities often experience unpleasant moments connected with the problem of employment and occupation, when they were evaluated as nonprospective employees on the basis of disability, a disabled woman who chooses to have a baby before pregnancy and birth can hear the statements of doctors that people with disabilities should not have children; doctors often refuse to treat people with thermal illness, elderly, persons with drug disability, people with severe physical and / or intellectual disabilities, etc.).

Thus, in our society most people with crippled corporeality are in the environment, which makes them vulnerable and weaker than it could be, it they were in better conditions of life for themselves.

The set of internal and external negative factors of socialization helps to ensure that people with mutilated corporeality are potentially more prone to committing a crime and becoming a victim of crime than people with full body.

In the mind of a person with crippled corporeality it is necessary to form a self-image of a successful, happy person, able to live a full life; to instill the idea that his (her) capabilities are not so limited compared to other people, whose capabilities are also limited to a certain extent.

(C) Siberian Federal University. All rights reserved

* Corresponding author E-mail address: poty-lyubov@yandex.ru 
Purposeful work on the formation of a harmonious positive self-image of a person with crippled corporeality is an important component of the work on the prevention of victimization of people with mutilated corporeality in modern Russian society. This area is closely interrelated with the other two areas of work for the prevention of victim behavior in which we are interested: by improving external conditions of socialization of people and by formation of an adequate image of a person with crippled corporeality in the social consciousness of modern Russian society.

Keywords: victimize, victim behavior, victimization, criminalization, socialization, person with defective exalted body, self-image, victim preventive measures.

DOI: 10.17516/1997-1370-2015-8-9-1877-1885.

Research area: philosophy.

Victim behavior (from the Latin. "Viktima" - the victim) is a provocative type of behavior of the person for committing criminal attacks against him (her). Victimization can be understood as a process and a result of becoming a victim. It is known that criminalization (the process and the result of the formation of a criminal) and victimization are closely interlinked with each other and have largely the same reason. The probability that a person who (especially in childhood or adolescence) was a victim of crime in the future can commit an unlawful action is much higher than the probability of a wrongful act of a person who has never been a victim of a crime (Gaptelganiev, 2010). Accordingly, a set of measures for the prevention of criminal behavior must include the prevention of victimization.

According to V. Burlakov, every nation has its own "threshold of saturation of crime", and it depends only on the limit of patience of the people. In other words, every nation has such a crime rate, which it allows to exist and that can be endured. In this way people expresses their victimological position (Burlakov, 2000). The crime rate and, consequently, the level of victimization of the modern Russian society are extremely high. Therefore, the task of improving the work on the prevention of victimization of citizens of modern Russia is very urgent and needs immediate action.
Particularly susceptible to victimization and often already victimized are people with crippled corporeality.

In modern psychological and philosophical literature, the concept of physicality overcomes the opposition between the body-physical and intellectual, spiritual qualities of human, between "solid human" and "spiritual human"(spiritualized body, a special phenomenon, which occupies the space between the body and soul). In a paper of V.A. Podoroga we encounter such a notion as a "mutilated body", which scholars determine as "a body that has been affected", i.e. was in a state of physical and mental damage, "disability", "lack of something" or "incompleteness" (Podoroga, 2007, p. 109). The term "crippled physicality" can be related to any cases of physical and / or mental developmental disorders that require the creation of special conditions for education, employment, a number of aspects of life.

In our works when describing people with crippled body we primarily mean persons with disabilities, who can be subdivided into people with physical disabilities, people with intellectual disabilities and people with a poor emotional and volitional sphere. People with mutilated corporeality also include people with drug addiction; they can be defined as people with drug disability and people with other types of sustainable and self-destructive addictive behaviors (alcohol, gambling, food addiction, 
etc.). We believe that other categories of people with crippled body include people with thermal disease, people of old age with mental and / or physical age-related changes that severely restrict opportunities of their life, people who have suffered severe physical and / or psychological violence on their physical and / or body of their loved ones (rape, beating, terrorist attack, existence in inhuman conditions, for example, in concentration camps, in the midst of armed conflicts, etc.).

Almost all people with crippled body need special, the best for them, conditions of socialization. Targeted, comprehensive, consistent influence of the main institutions of socialization for people with mutilated corporeality is more important than for people with full corporeality.

However, human physicality often becomes crippled by the impact of unfavorable conditions of socialization. Subsequently, a person with the already crippled corporeality may continue to be adversely affected by basic institutions of socialization. Thus, in the further crippled physicality of life there is often a person who has something that has not been healed, and even more damaged than it was originally (since its initial injury).

This is the case for most countries in the world. For example, according to the UN, according to a study conducted in 2004 in the UK, people with disabilities are much more likely to become victims of violence, rape, and to a lesser extent get protection from the police, legal and preventive services. Cases of violence against children with disabilities 1.7 times are more likely to occur than their peers who are not disabled (URL:http:// www.un.org/russian /disabilities/ convention/facts/shtml). This is despite the fact that in the UK, as in other Western countries over the past forty years there have been significant positive changes in the attitude of the society towards people with disabilities. Ill-treatment of human crippled corporeality in these countries today is condemned and punishable by the society. In a number of other states disrespectful and sometimes harsh and cruel treatment of certain categories of people with mutilated corporeality is a daily norm. In particular, a small study conducted in 2004 in India, found that almost all (!) disabled women and girls with disabilities were subjected to beatings at home, $25 \%$ had been sexually abused (ibid) (a large percentage, of course, can be associated with cultural characteristics of India, generating a huge number of superstitions against persons with disabilities, as well as prejudice against women). Countries such as China, Thailand, North Korea, Iran, United Arab Emirates and several others, are known for their extremely stringent penalties not only for the production, distribution, but also for the storage and use of drugs. Accordingly, the attitude to human physicality with drug disability in these countries can be characterized as fairly rigid (up to the death penalty).

In today's Russian society there is an increase of crimes against vulnerable people (pensioners, orphans, people leading asocial way of life, as well as people with disabilities) (http://www. REGIONS.RU; kasparov.ru > material.php...). However, detailed statistics on this issue today in our country is not available.

However, it is clear that people with mutilated corporeality in modern Russian society are subjected to constant discrimination. Rights of such people to education, employment, freedom of movement, preferential, high-quality treatment, and so on are violated everywhere. As a result, corporeality of the overwhelming majority of people with mutilated body sorely experienced lack of money (and, hence, poor nutrition, not always high-quality medical care and so on), extremely limited living space, the inability to fulfill themselves properly, indifference / rejection / cruelty / frightened pity of others, etc. 
Modern Russian society creates a large number of stressful situations for people with mutilated corporeality (in particular, many people with disabilities often experience unpleasant moments connected with the problem of employment and occupation, when they were evaluated as non-prospective employees on the basis of disability: a disabled woman who chooses to have a baby, before pregnancy and birth can hear the statements of doctors that it is not necessary to have children for people with disabilities; doctors often refuse to treat people with thermal illness, elderly, persons with drug disability, people with severe physical and / or intellectual disabilities, etc.).

Why is this happening? Probably, primarily because many of us are still not ready for the final recognition of equal fellow citizens with healthy social status of people with certain kinds of crippled body. In the public consciousness of the modern Russian society firmly established a mistaken notion that a reduction in functionality of a person automatically leads to narrowing the scope of his (her) needs. Nonsense, but in the minds of quite a large number of people certain categories of persons with crippled body are deprived of even such basic human needs as love and security. As an example we can use the words of a worker of a boarding school for children with severe disabilities: she was asked why she had hidden the fact of sexual violence committed against one of the pupils, and said the following: "she is a disabled person anyway, so what is the difference for her?"

Thus, in our society most people with crippled corporeality are in the environment, which makes them vulnerable and weaker than it could be, it they were in better conditions of life for themselves. It is no exaggeration if we say that the community of people with mutilated corporeality in modern Russian society in a figurative sense can designate a certain

\section{collective victim, since those severe restrictions} of life in which many of these people have to live, in fact, is nothing but a crime against them, which is being committed by the society.

Inadequate public attitudes towards people with crippled body, imperfection of external factors of socialization, and, respectively, systematic pressure on people with mutilated corporeality in stressful situations often leads to more damage for their psyche-the deterioration of the psychological state, a sense of worthlessness, lack of demand, uselessness, etc. This perception of themselves generates the corresponding traits of character and behavior. Many people with crippled body in our country can be characterized by such features as isolation, passivity, and the dominance of the motive of avoiding failure propensity to addictive behavior. These personal qualities further complicate the life of a person with crippled physicality, making it more difficult to find employment, choice the circle of friends, family, etc.

The set of internal and external negative factors of socialization helps to ensure that people with mutilated corporeality are potentially more prone to committing a crime and becoming a victim of a crime rather than people with regular body.

We believe that the work on the prevention of victimization ofpeoplewithmutilated corporeality in modern Russian society should be conducted in the following, closely interrelated areas: 1 . Improving external conditions of socialization of people with mutilated corporeality. 2. Formation of an adequate image of a person with crippled corporeality in the public consciousness. 3 . Correction of the self-image of a person with crippled corporeality.

Professionals, who work with people with crippled physicality, and those who know these people in the first place (provided a competent approach) can actually implement a corrective 
effect on the self-image of a person with crippled body, since the first two steps for the prevention of victim behavior of such people necessarily involve coordinated work of the main social institutions (the state, educational system, health system, media, churches, and others.) in all spheres of society (economic, political, legal, social, spiritual).

The self-image (or self-concept) of a human is his (her) understanding of himself (herself) and his (her) role in the world. The system of the self-image contains such elements as "I-real" and "I-ideal". For people with disabilities cases of very strong discrepancies between the "I-real" and "I-ideal" are quite typical. The structure of the self-image can be viewed as a collection of a specific "I-real" and "I-ideal" images: the image of the body, the image of thinking, the image of myself as a professional, the image of myself as a family member, the image of myself as a student and others. It is obvious that in certain constituents the self-image of "I-real" and "I-ideal" can almost completely coincide, yet in other cases they diverge significantly. Thus, according to I.V. Postavneva, patients with disorders of the locomotor area are most vulnerable in terms of a mental image of their body (Postavneva, 2002).

Obviously, the self-images of people with mutilated corporeality will vary significantly depending on the nature of the damage in their physicality (a particular case of physicaldisability, intellectual disorders, emotional and volitional, drug disability, thermal disease, senile impotence, post-stress syndrome, etc.).

So, particular properties of the self-image and the circumstances of the lives of people with disabilities (both congenital and acquired) often contribute to quite a favorable result of their socialization. But the emergence of a drug disability indicates that, firstly, the conditions of socialization of the person in varying degrees were unfavorable, even though they seem to be optimal, and, secondly, the fact that the self-image of this person had been damaged even before the initial reception of psychotropic substances. It is known in particular that to addictive behavior are inherently more prone people, who have certain inherent features of the psyche (in particular, the presence of genes that cause deviations in the neurochemical mechanisms regulating mood (the so-called gene of satisfaction deficiency syndrome) and personal traits of character, which are formed on this basis, (impulsivity, depression, instability, "blurriness" of individual values, value orientations, goals, perceptions of social norms and rules of conduct for oneself and others). So we can say that the physicality of a person with an addictive tendency (potentially addictive) is a kind of crippled physicality too, carrying a latent threat to the security of the person and people around him (her) and society as a whole. These children originally need special, optimal for them, conditions of socialization and methods of correction.

According to G.I. Bondarenko, the essence of the self-concept (self-image) of a disabled person is the movement of his (her) potential: from "I-potential" (marginality) to "I-normal" (completeness) (Bondarenko, 2006, 39).

M. Hall, B. Bodenhamer believe that in the "I" of a person in the first place there are following meta-programs (programs that stand above the daily thoughts and emotions): self-esteem, selfconfidence, self-awareness, self-completeness. Self-esteem is defined as an estimate of self worth and dignity of being associated with our ontological "I". Self-esteem can be in any place of the continuum between total futility (disgust), and a special value (self-esteem from low to high). Self-confidence is a sense of competence, which is related to our understanding of our own abilities, skills and a sense of pride from their possession. Self-confidence stems from our experience (positive and negative), education, 
beliefs, relationships, etc. It relates more to the emotional / experiential factor of "I", while self-esteem or self-respect relate to the mental evaluation of ourselves as individuals. The selfawareness that people differ from each other by their existing concept of "I" and factors that are used in the determination of yourself first (thinking, emotions, your will, body, your role). The way a person defines himself (herself) plays a central role in the "I", from which it emanates, and the "I", which he (she) uses at the meta-level. The individuals may be inclined to think, to identify themselves with their thoughts or their feelings. Others define themselves primarily through their work roles, experience, knowledge, etc. Self-completeness: 1 . Those who find that their ideals and ideal "I" correspond to their actual experience, feel this "completeness". This feeling leads to self-acceptance and self-centering. As a result, a person is able to more effectively direct mental and emotional energy to updating his (her) values and beliefs. 2. Those who do not have this sense of conformity between "I am real" and "I am ideal" feel the inner dichotomy and are at odds with each other. This often leads to a large expenditure of energy to internal conflicts and struggles with himself (herself), negative emotions and self-reproach (Hall, Bodenhamer, 2007, pp. 211-217).

As a result due to the systematic contact with stressful situations people with crippled physicality do not have a necessary level of psychological security and distort all metaprograms of "self": self-esteem tends to lower (down to worthlessness of "I"), there is a lack of confidence, often there is a lack selfcompleteness that can lead to auto-aggressive behaviors, victim behavior. In addition, such people often define themselves primarily through a disease or a defect that promotes the development of a dependent position in relation to the society. I.A. Shapoval defines this condition as presence of a special concept in the internal picture of the disease: the concept of the overvalued self-suffering in relation to all other motives for life (Shapoval, 2005 s.150-151).

Acquired disorders of physicality have particularly strong effect on the components of the self-image. For example, when a person experienced a primary violation of physical component the most self-esteem and selfconfidence are reduced in people with crippled physicality, for whom body self-awareness and visual appeal was the leading factor. And those whose self-confidence depended primarily on the possibility of self-realization through physical activity. It has been observed that people with acquired disabilities, who after the damage of physicality do not have strong divergence between the "I-ideal" and "I-real" image as a professional, beloved spouse (s), parent, etc. much easier cope with the necessity to live with their new physical features.

However, in the minds of people with mutilated corporeality always there is a potential to compensate for (and overcompensation) disturbed systems. Compensatory mechanisms may be involved at all levels of the socialization process: physiological, psychological, sociopsychological and social (Sorokin, Kokorenko, 2003).

So, on the psychological level protective mechanisms are included in the work, i.e. the unconscious processes that reduce anxiety and internal tension in stressful situations, as well as so-called "coping strategy", that is a conscious effort of the individual to maintain positive selfesteem in a threatening situation (Ibid, 67-68). To protect themselves from the devastating impact of the prevailing social attitudes towards crippled physicality, a person with disabilities should possess such mechanisms of psychological protection as direct compensation, sublimation, substitution, analyticalidentification, depreciation, 
an adequate self-assessment based on the selfconcept, etc. . (Zotov, 1997). So, for successful auto-adaptation of a person with a physical disability you must take your own body image as a component of its uniqueness and individuality with not only disadvantages but also advantages (Bondarenko, 2006, 39); in the case of medical faux pas, disabled women wishing to give birth and raise a child, you must immediately turn the mechanism of depreciation of the significance of such statements, and others.

In general, it is quite possible to form a positive self-image for a person with a crippled body. To achieve this, today there are different methods of psychological correction. The main objectives of this psycho (and psychoprophylactic) work can be defined as follows: 1. training in the psycho-emotional state of self-control; 2. normalization of self-esteem (in the direction of the sustainable, adequate self-esteem); 3. The development of active position in life - the predominance of the motive to achieve success, not the motive of avoiding failure; 4. The formation and strengthening communication skills of successful communication in various situations (most notably, the ability to understand other people).

In the mind of a person with crippled corporeality it is necessary to form a self-image of a successful, happy person, able to live a full life; to instill in this person an idea that his (her) capabilities are not so limited compared to other people, which may also have limited capabilities to some extent.

We have developed a method of psychological treatment for people with mutilated corporeality, which involves a combination of such methods of social and cultural rehabilitation as bibliotherapy, elements ofmusic therapy, play therapy, isotherapy, some computer technologies, opportunities of modern technology (photo and video) as well as a number of elements of emotional and expressive training (EET), a method of visualization (i.e. a concerted effort of the individual person with crippled body by the emergence of certain images of the world in his (her) mind. In our view, psycho and psychoprophylactic class must be built in such a way that people with disabilities do not feel that they are patients attending a therapist. Psychological adjustment should be carried out primarily by means of creative rehabilitation (Nagorny, Nagornaya 2011, 386-387).

Thus, the purposeful work on forming a harmonious positive self-image of a man with a crippled corporeality is an important component of the work on the prevention of victimization of people with mutilated corporeality in modern Russian society. This area is closely interrelated with the other two areas of work for the prevention of victim behavior we are interested in: improving external conditions of socialization of people and formation of an adequate image of a person with crippled corporeality in the social consciousness of modern Russian society.

\section{References}

1. Bondarenko, G.I. Ya-kontseptsiia cheloveka s invalidnost'iu [Self-concept of a person with disability (Defectology)]. 2006. № 5. pp. 36-40.

2. Burlakov V.N. Kriminologiia Dvadtsatogo Veka. Elektornnaia Biblioteka Prava [Criminology of the Twentieth Century. Electronic Library of Right]. Available at http: // www. gumer.info> bibliotek_Buks / Pravo / burlak / 08.php. (Accessed 1.09.2015)

3. Gaptelganiev R.G. Viktimizatsiia kak protsess realizatsii kriminal'noi viktimnosti [Victimization as a process of realization of criminal victimization (Russian investigator). 2010. № 23. Pp. 19-22]. 
4. Zotov A.M. Integratsiia rebenka-invalida v sredu zdorovykh sverstnikov kak metod sotsial'noi adaptatsii [Integration of a disabled child in the environment of healthy peers as a method of social adaptation (Defectology)]. 1997. № 6. Pp. 21-24.

5. Nagornaya L.A., Nagorny N.N. Sotsializatsiia cheloveka s ogranichennymi vozmozhnostiami razvitiia: proshloe, nastoiashchee, stsenarii budushchego [Socialization with disabilities development: past, present and future scenarios: monograph]. Krasnoyarsk: Siberian Federal University, 2011.

6. Podoroga V.A. Polnoe i rassechennoe [Full and dissected (Psychology of physicality between the mind and body) ed. by T.S. Zinchenko, T.S. Levi]. AST Moscow, 2007. Pp. 67-139.

7. Postavneva I.V. Osobennosti obraza tela u detei doshkol'nogo vozrasta, imeiushchikh fizicheskie defekty [Features in the image of a body in preschool children with physical defects (Defectology). 2002. № 4. Pp. 72-80].

8. Sorokin V.M, Kokorenko V.L. Praktikum po spetsial'noi psikhologii [Workshop on special psychology]. St. Petersburg: "Rech", 2003.

9. Hall M., Bodenhamer, B. 51 metaprogramma NLP. Prognozirovanie povedeniia, "chtenie" myslei, ponimanie motivov [51 metaprogram of NLP. Prediction of behavior, reading of thoughts, understanding the motives]. SPb: Prime - EVROZNAK, 2007.

10. Shapoval, I.A. Spetsial'naia psikhologiia [Special psychology: Textbook] Moscow, TC Sphere, 2005.

11. Electronic resource. Available at http: //www.REGIONS.RU; kasparov.ru> material.php ...(Accessed 01.09.2015)

12. Electronic resource. Available at http: //www.un.org/russian / disabilities / convention / facts / shtml(Accessed 01.09.2015) 


\title{
Коррекция Я-образа как одно из направлений работы по предупреждению виктимизации людей \\ с искалеченной телесностью \\ в современном российском обществе
}

\author{
Л.А. Нагорная ${ }^{a}$, Н.Н. Нагорный ${ }^{0}$ \\ ${ }^{a}$ Сибирский федеральный университет \\ Россия, 660041, Красноярск, пр. Свободный, 79 \\ Россия, 660131, Красноярск, ул. Рокоссовского, 20
} ${ }^{6}$ Сибирский юридический институт ФСКН России

В статье анализируются причины виктимизации людей с искалеченной телесностью. Отмечается, что условия социализации таких людей в современном российском обществе способствуют формированию у них виктимного поведения. Обозначены основные направления работы по профилактике виктимизации людей с искалеченной телесностью в современном российском обществе. Показаны основные положения работы по формированию положительного Я-образа человека с искалеченной телесностью как одно из направлений работы по профилактике виктимного поведения людей с искалеченной телесностью.

Ключевые слова: виктимность, виктимное поведение, виктимизация, криминализация, человек с искалеченной телесностью, сочиализация, Я-образ, виктимологическая профилактика.

Научная спеииальность: 09.00.00 - философские науки. 